International Journal of

Advanced Science and Convergence

\title{
Adoption Determinants of a Learning Management System in a Higher Education Institution: A Faculty Perspective
}

\author{
Hector John T. Manaligod ${ }^{1}$, PhD, Rogelio V. del Cano ${ }^{2}$ and Jelica R. Enriquez ${ }^{3}$ \\ ${ }_{1,3}$ Computer Applications Program, School of Management and Information Technology, De La Salle-College of \\ Saint Benilde, Manila, 2544, Philippines \\ ${ }^{2}$ Information Systems Program, School of Management and Information Technology, De La Salle-College of \\ Saint Benilde, Manila, 2544, Philippines
}

\begin{abstract}
Background/Objectives: The study sought to investigate technology adoption and use of learning management system (LMS) in a university. The study included antecedents of behavioral intention (BI) namely: performance expectancy (PE), effort expectancy (EE), social influence (SI), and facilitating conditions (FC) and its relationship with actual use LMS. Methods/Statistical analysis: The research used self-administered on-line survey method and actual use based on data registers from LMS. Random samples were drawn from the faculty population who are using LMS. A multivariate statistical analysis and factor analysis were applied to find structural relationship among the variables and latent constructs (structural equation modeling). The instrument registered high internal consistency and validity. Findings: The results revealed that $\mathrm{PE}, \mathrm{EE}, \mathrm{SI}$ significantly explained the variation in $\mathrm{BI}$. The $\mathrm{BI}$ and $\mathrm{FC}$ are not significantly related to LMS actual usage. Overall, there is a strong positive intercorrelation among the $\mathrm{BI}, \mathrm{PE}, \mathrm{EE}$, and $\mathrm{SI}$. Moderating effects were found in age and experience in the relationship between $\mathrm{Fl}$ and actual usage; between EE and BI. Improvements/Applications: Data suggested a strong faculty behavioral intention to use LMS, but this did not translate into a substantial level of actual usage.
\end{abstract}

\section{Index Terms}

education technology, ePortfolio, faculty adoption of LMS, faculty resistance to LMS, learning management system, Unified Theory of Acceptance and Use of Technology, virtual learning environment

\footnotetext{
Corresponding author : Hector John T. Manaligod

hector.manaligod@benilde.edu.ph

- Manuscript received January 28, 2019.

- Revised February 12, 2019 ; Accepted March 22, 2019.

- Date of publication March 31, 2019.

(c) The Academic Society of Convergence Science Inc.

2619-8150 () 2019 IJASC. Personal use is permitted, but republication/redistribution requires IJASC permission.
} 


\section{INTRODUCTION}

Connecting the mission and vision statements of an institution to the "role of learning technologies" is the most crucial step in technology implementation [1]. In fact, integrating a learning management system (LMS) to the traditional classroom management can be tedious [2]. Before the Higher Education Institution in Taft Avenue, Manila switched to its new learning management system, it had used Moodle for several years. Moodle is free and open-source software learning management system used for blended learning, distance education, flipped classroom and other e-learning projects in schools, universities, workplaces and other sectors.

Currently the Higher Education Institution in Taft Avenue, Manila is using BrightSpace; a proprietary learning management system used for administering, documenting, tracking, reporting and delivering electronic educational technology; but in spite of the effort made by the EdTech Office, some faculty members are still not yet embracing the current LMS to their day-to-day teaching-learning activities and processes.

Further research is needed to explore the different factors on how teachers adopt new technology [3]. The Higher Education Institutions understand that there are many benefits of using a learning management system [4]. One of the challenges in implementing an LMS is influencing the end users in using a new technology. Technophobia and "lack of motivation" are some of the reasons why users are hesitant in adopting an LMS [1]. To entice the faculty members the Higher Education Institution in Taft Avenue, Manila has rebranded BrightSpace as LMS and provided them with group training, one-on-one consultation, and self-starter website; however, $70.5 \%$ of faculty members are still not fully utilizing the said learning management system [5]. This results to an adoption concerns among the faculty, and on the other end, a loss opportunity for students because those students do not get the chance of taking advantage of the said learning system.

The main objective of this study is to investigate the reasons for faculty adoption of and/or resistance to using LMS.

\section{A. Purpose of Statement}

The purpose of this study was to test the Unified Theory of Acceptance and Use of Technology's (UTAUT) by Venkatesh, Morris, Davis, \& Davis. The UTAUT is a unified model that uses four core determinants namely Performance Expectancy (PE), Effort Expectancy (EE), Social Influence (SI), and Facilitating Conditions (FC) towards determining attitudes for using and accepting a learning management system in a Higher Education Institution in Taft Avenue, Manila. The independent variables were defined as the adoption constructs as stated in the UTAUT. While the dependent variable was defined as the LMS actual level usage. The moderating variables were represented as the gender, age, and LMS experience.

\section{B. Significance of the Study}

This study tested the Unified Theory of Acceptance and Use of Technology (UTAUT). This theory was used to find the best explanation to the adoption or resistance of faculty to using a learning management system. The findings of this study may benefit not only the Higher Education Institution in Taft Avenue, Manila, but also all other institutions that are interested to implement a learning system, particularly to the integration of the learning management system to the teaching and learning processes of the faculty members. In addition, it may also provide information on the successful adoption of a learning management system. The research results may also help the academic community in determining some factors that lead to the resistance in using learning management systems. Likewise, it may provide insights to the administrators in addressing the barriers that other faculty may experience during the transition to adopting a learning management system.

Finally, the results of this research may also benefit the EdTech Office or any related center or department in their process reviews, delivery of services, faculty development, and strategic planning.

\section{Scope and Delimitation}

The scope of this study seeks to determine the factors that are significant to the adoption of a learning management system.

This study was conducted last 2nd Term of School Year 2017-2018 at Higher Education Institution in Taft Avenue, Manila specifically to 101 faculty from the various programs in different schools such as SDA, SDEAS, SHRIM, SMIT, and SMIT.

The researchers selected a sample group that is representative of the population of Higher Education Institution in Taft Avenue, Manila because the researchers wanted to ensure that all programs from different schools were represented.

This study did not include respondents such as administrators, academic service faculty, staff, and students. In addition, this study did not delineate the rank and status of faculty in determining the reasons for acceptance or resistance of a learning management system. Finally, this study did not distinguish access made by faculty to different devices, such as, but not 
limited to, smart phones, tablets, laptops, and desktop computers.

\section{Objectives}

1. Investigate if the following independent variables influence faculty's adoption and use of LMS.

a. Performance Expectancy (PE)

b. Effort Expectancy (EE)

c. Social Influence (SI)

d. Facilitating Conditions (FC)

2. Examine the role of facilitating conditions to the adoption of LMS.

3. Investigate the relationship of gender, age, and experience moderate in the use big sky and the independent variables.

\section{E. Research Problem}

Presently, the Higher Education Institution in Taft Avenue, Manila is using BrightSpace and rebranded it as LMS; however, $70.5 \%$ of faculty members are still not fully utilizing the said learning management system [5]. This results to adoption concerns among the faculty, and on the other end, a loss opportunity for students because those students do not get the chance of taking advantage of the said learning system. The main objective of this study is to investigate the reasons for faculty adoption of and/or resistance to using LMS that leads to the following questions.

\section{F. Research Questions}

This study sought to answer the following research questions:

\section{1) Central Question:}

What are the factors that influence the Higher Education Institution in Taft Avenue, Manila faculty members' adoption of an LMS in the teachinglearning process?

2) Sub-questions:

1. How significant are the following variables in influencing faculty's use of LMS?

a. Performance Expectancy (PE)

b. Effort Expectancy (EE)

c. Social Influence (SI)

d. Facilitating Conditions (FC)

2. Do perceived facilitating condition substantially affect the use of LMS among faculty including possible moderating effects of Age and Experience?
3. Will the following moderating variables influence the strength of relationship between the independent variables and dependent variables?
a. Gender
b. Age
c. Experience

\section{G. Operational Definitions}

- Performance expectancy (PE) is the degree to which the users expect that using the system will help them to attain gains in job performance [6].

- Effort expectancy (EE) is the degree of ease associated with the use of the system [6].

- Social influence (SI) is the degree to which individuals perceive that important others believe they should use the new system [6].

- Facilitating condition (FC) is the degree to which individuals believe that an organizational and technical infrastructure exists to support use of the system [6].

- Behavioral intention (BI) refers to a desire or a purpose and is a direct determinant of the actual use [6].

- LMS Usage is the level of usage based on the number of tools and quadrant(s) used by the faculty member. Quadrants are classified as records, contents, assessment, and engagement.

\section{REVIEW OF RELATED LITERATURE}

\section{$(\mathbf{L M S})$}

A. Overview of Learning Management System

Throughout the years, the development of information technology (IT) applications has progressed and has met the rising needs of our society [7]. One of the areas that information technology continuously supports is the education system. Development of IT applications provides efficient learning approaches in college-level institutions [8] and in organizations offering vocational trainings [9]. Electronic learning or e-learning systems provide an avenue for improving the teaching approach [10] and present opportunities for users to store information and media, record data, share teaching resources, undertake research, and interact with each other anytime, anywhere [11]. There are "more than 250 commercial e-learning systems and more than 45 free Open Source Software (OSS)" applications [12] [1]. The application of available IT tools in schools is 
determined by how the users, such as the faculty members, accept them [13].

The learning management system (LMS) for education is a tool that enables faculty members to facilitate a web-based class [14]. Faculty members can monitor, support, and assess students in LMS [15]. LMS users can also apply "synchronous and asynchronous technologies" [2] [26]. Some of the features of LMS are the following: management and administration of course delivery, video conferences, online discussion forums, grading system, academic calendar, online messaging, "training programs, classroom and online events, e-learning programs, and training content" [16]. Examples of LMS are Blackboard, WebCT, Moodle, and BrightSpace.

\section{B. Adoption of LMS}

Considerations must be reviewed before introducing, integrating, and using new technologies in higher education institutions [10]. The most crucial step in technology implementation is connecting the mission and vision statements of an institution to the "role of learning technologies" [1] [48]. Thus, it is necessary for an institution to look at its long-term goals before rolling out new technology.

\section{Challenges of LMS}

Integrating LMS to the traditional classroom management can be tedious [2]. The hardware and software requirements for building an e-learning facility are costly [17]. These have also become more expensive due to the intricacy of setting up and maintaining such system. However, the authors note that it is still imperative to establish a stable infrastructure foundation so that the users can efficiently use the platform.

Another challenge in implementing LMS is influencing the end users in accepting and using this new technology. It is important to consider that there is initial uneasiness in implementing and using a new system. LMS applications are standardized that respond to different teaching pedagogies. Aside from studying the profiles of the learners and profiles [18], it is also important to understand the users' attitudes regarding technology adoption [19].

\section{Resistance to LMS}

Integrating a new technology to a prevailing system in a college institution can be disruptive [20]. Although faculty members appreciate how web-based technology positively affects today's education, they admit that technophobia and "lack of motivation" are some of the reasons why they are hesitant in adopting LMS [1] [47]. Aside from the financial costs incurred in the implementation, teachers who are new to such technology experience a learning curve [21]. There may also be a misalignment of cultures between implementation of the management and pedagogy of the faculty [21]. Other factors that hinder LMS adoption of faculty members are lack of time to learn the technology [22], lack of infrastructure and technical assistance to the users [23] [22], identification of the complexity of learning a new technology [1], and technical problems such as "slow system response", "lack of integration of notification apps", and "formatting issues" [24] [46].

\section{E. Benefits of LMS}

Studies show that there are various benefits of utilizing LMS in education. These benefits include faculty members' positive attitudes towards creating online forums [4], customizing quiz structures, sharing learning materials [25], using different methods of communication with students [24], overlooking and measuring the students' progress [16], and contributing to students' progress by transforming information quality [4]. It is probable that LMS applications can help build an effective learning environment as it offers functions and features that can improve traditional classroom activities [12].

\section{F. Technology Adoption Model (TAM)}

Information technology practitioners aim to know if users will be able to accept a new system, determine the possible reasons why it is not acceptable to some, and implement necessary changes to improve the change process [26]. The adoption theory is a potential enabler of change that concentrates on the elements of the change process [27]. It explores on how a user accepts or rejects a technology. The Technology Acceptance Model (TAM) is one of the most recognized models used to study adaptation and integration of new technologies [28]. TAM, which was adapted from the Theory of Reasoned Action, was developed to distinctively study technology acceptance of a user [29]. TAM was established to study the different factors that influence individuals in accepting new technology applications [26]. The main goal of TAM is to present a foundation of examining how external factors affect internal principles, attitudes, and intentions [26].

Perceived usefulness (PU) and perceived ease of use (PEOU) were presented as two determinants in studying the causes on why users accept or reject technology [30]. Perceived usefulness is defined as "the degree to which a person believes that using a particular system would enhance his or her job 
performance" while perceived ease of use is "the degree to which a person believes that using a particular system would be free of effort" [30] [320]. Based on TAM, a user can be influenced by these factors: his "behavioral intentions, attitude, perceived usefulness of the system, and perceived ease of the system" [28] [151]. If a particular system is easy to use, offers benefits, and provides greater "perceived control" [31] [395] to a user, a user's attitude and intention will be more positive in utilizing and accepting the new technology [32]. The visual framework of TAM in Figure 1:

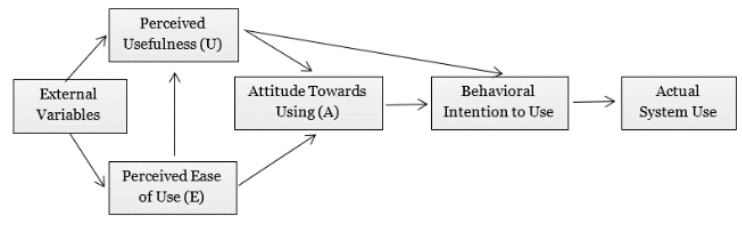

Fig. 1. Technology Acceptance Model (Source: Davis, Bagozzi, \& Warshaw, 1989).

\section{G. Unified Theory of Acceptance and Use of Technology (UTAUT)}

Venkatesh, Morris, Davis, and Davis developed the Unified Theory of Acceptance and Use of Technology (UTAUT) based on the following theories and models related to technology acceptance: the Theory of Reasoned Action, the Technology Acceptance Model, the Motivational Model, the Theory of Planned Behaviour, the Model of PC Utilization, Innovation Diffusion Theory, and Social Cognitive Theory [33]. It is a unified model that uses four core determinants and it is moderated by gender, age, experience, and voluntariness of use [6].

The four core determinants are performance expectancy, effort expectancy, social influence and facilitating conditions. These constructs directly affect behavioral intention:

1. Performance Expectancy (PE) - the degree to which an individual believes that using technology will benefit him in his or her work performance.

2. Effort Expectancy (EE) - the degree of an individual's ease of use with a particular technology.

3. Social Influence (SI) - the degree to which an individual understands that it is important for others to use a technology.

4. Facilitating Conditions (FC) - the degree to which an individual believes that there are existing organizational and technical infrastructures to sustain the use of technology.

The four moderating variables are gender, age, experience, and voluntariness of use [6]. The inclusion of the said variables in the proposed
UTAUT was based on how these variables are linked to the four core determinants. Research results present the following:

1. Task accomplishment and perceived usefulness are more important for men.

2. Ease of use is more important for women.

3. Women are perceived to be more sensitive to others' opinions. Thus, social influence is a significant factor for them.

3. Effort expectancy is more important for women and for older workers who have "relatively little experience with the system" [450].

Increased age is linked to "processing complex stimuli" which may be required in dealing with new technology [450]. Experience refers to the degree of an individual's usage involvement with the system while voluntariness of use is the degree on how an individual is willing to use a particular technology.

The UTAUT model is presented in Figure 2:

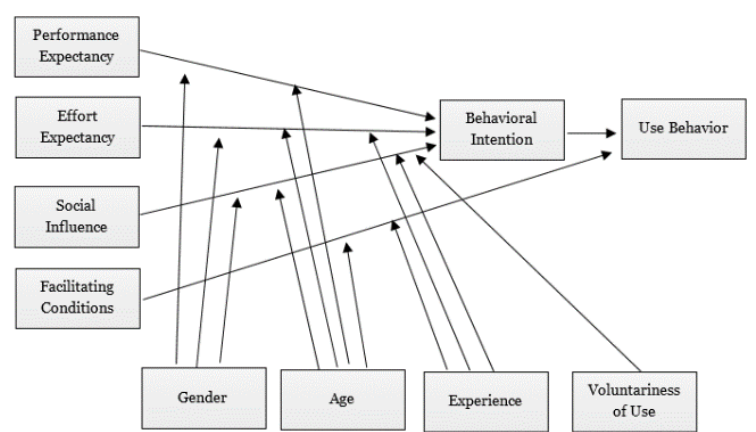

Fig. 2. Unified Theory Acceptance and Use of Technology Model (Source: Venkatesh, Morris, Davis, \& Davis, 2003).

This model has been widely used in research related to acceptance of technology adoption and diffusion, [33] and in schools to determine an individual's attitudes towards using and accepting a new technology [34]. UTAUT was applied in research [8] because of its extensiveness and it has also "increased the predictive efficiency to $70 \% "$ [29] [256] as compared to other technology acceptance models.

\section{H. Local Studies}

In the Philippines, the Commission on Higher Education (CHED) issued policies requiring higher educational institutions (HEIs) to prioritize and apply information technology in the teaching and learning processes [37] [38]. HEIs have started using LMS such as Moodle in Jose Rizal University [39], Toondoo in Mindanao State University [37], and the information management web portal of University of the East [40]. There are HEIs that have implemented blended learning such as Malayan Colleges Laguna and have offered online degree programs such as 
University of the Philippines, De La Salle University, Ateneo de Manila University, and Polytechnic University of the Philippines [41]. Considering that there are HEIs that have implemented LMS, it was revealed that studies on the significance of online learning in the Philippines is limited [42].

Some of the local findings related to using an LMS in HEIs are as follows:

- An adequate teacher workshop is a significant part of a notable learning process that is based on technology such as LMS [37].

- Teachers who are more confident in using technology in their courses will most likely influence their students to use technology [43].

- A research must be conducted to determine if a course can be taught in an online learning environment [44].

- For teachers, using an information management is manageable and accessible. They also purposely use their implemented system [40].

\section{Synthesis}

A learning management system is an important tool for faculty members because they can monitor, provide support, and assess students. LMS can be used for the management, delivery, and administration of various teaching-learning related activities. In addition, faculty members have a wider range on the delivery of learning sessions because an LMS can be used either on synchronous or asynchronous mode.

However, faculty members do not use LMS because they are threatened due to technophobia [1] [47]. Some of them do not use it because they do not have time to learn a new technology [22]. While others are frustrated because of a slow connection or system response and because of the limitation of apps that may support some faculty requirements [24] [46]. Locally, teachers who are confident in technology will most likely influence their students [43] and if the information management is manageable and accessible, teachers will use that particular technology [40]. However, adequate workshop on the use LMS is needed [37] and a course must be determined if it can be taught in an online environment [44].

Similarly, the researchers were interested to find out if the above-mentioned reasons apply to the Higher Education Institution in Taft Avenue, Manila. Thus, to discover the adoption determinants of the faculty in the said institution, the researchers used UTAUT because it has determinants namely performance expectancy, effort expectancy, social influence, and facilitating conditions and moderating variables such as gender, age, and experience that fit to the requirements of the researchers.

\section{Conceptual Framework}

\section{A. Narrative Discussion}

Based on the research problem and the potential use of theories that have been identified from the review of the literature section of this paper, the researchers recognized the need to conduct a study to test the Unified Theory of Acceptance and Use of Technology's construct within the confines of the case site [6]. This theory was used as the conceptual framework of this paper and to find best explanation to the adoption or resistance of faculty to using a learning management system (LMS).

This chapter explains the relationships among the independent and dependent variables through the moderating variables. Further, the result of the survey explains the relationships between the predictor and outcome variables most especially when the relationships among the independent and dependent variables become non-significant.

The researchers anchored their independent variables from the UTAUT [6]. These independent variables are performance expectancy (PE), effort expectancy (EE), social influence (SI), facilitating conditions (FC), and behavioral intention (BI). While the dependent variable is the actual LMS usage level [5]. There are similarities between UTAUT's constructs and TAM's determinants since the core determinants are derived from different technology acceptance models [6]. UTAUT's PE and EE represent the same idea as TAM's PEOU and PU [35]. Likewise, UTAUT integrated TAM's PU into its PE and PEOU into EE [36].

In addition, the moderating variables were based on the UTAUT [6]. These moderating variables are gender, age, and experience.

\section{B. Visual Representation of the Conceptual Framework}

Based on the research problem, this research utilized a framework based on the UTAUT [6]. In order to understand the relationships among the independent, dependent, and moderating variables, a visual model is shown below. The said conceptual framework shows that performance expectancy (PE), effort expectancy (EE), and attitude toward using an LMS predict the positive relation to the acceptance of LMS by faculty. Finally, the moderating variables measure the strength of the relationship among the independent and dependent variables. 

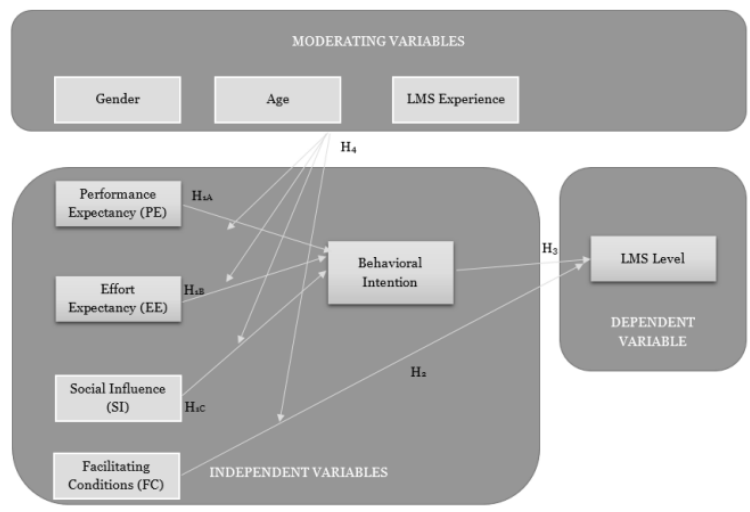

Fig. 3. Conceptual Framework

\section{Visual Representation of the Conceptual Framework}

Given the above-shown conceptual framework, the researchers tested the following null hypotheses:

$\mathrm{Ho}_{1}$ : Performance Expectancy (PE), Effort Expectancy (EE), and Social Influence (SI), have no significant relationship with the Behavioral Intention (BI) of the faculty.

$\mathrm{Ho}_{2}$ : Facilitating Conditions factor have no substantial association with the level of LMS Level with moderators such as Age and Experience.

$\mathrm{Ho}_{3}$ : Behavioral Intention has no significant relationship with LMS Usage.

$\mathrm{Ho}_{4}$ : Factors such as Gender, Age, LMS experience, do not significantly influence the relationship between the $\mathrm{PE} \rightarrow \mathrm{BI}, \mathrm{EE} \rightarrow \mathrm{BI}, \mathrm{SI} \rightarrow \mathrm{BI}, \mathrm{FC} \rightarrow \mathrm{LMS}$ Usage.

\section{Methodology}

\section{A. Research Design}

The study is a quantitative research using descriptive-correlational method. The descriptive method describes the different constructs identified in the Unified Theory of Acceptance and Use of Technology Model (UTAUT) and the actual faculty usage level of the Learning Management System (LMS). Bivariate and multiple correlation statistics were employed to test if there are significant relationship between and among the variables. The study used survey questionnaires which are selfadministered.

\section{B. Data Requirements}

The central question of this research is to find out the factors that influence the Higher Education Institution in Taft Avenue, Manila faculty members' adoption of or resistance to the use of a learning management tool in the teaching-learning process. To realize it, the researchers administered survey to 101 faculty members from the various programs in different schools.

To reiterate, the main source of data came from a survey questionnaire. The said questionnaire is derived from UTAUT that focused on the Performance Expectancy (PE), Effort Expectancy (EE), Social Influence (SI), Facilitating Conditions (FC), Behavioral Intention, gender, age, and experience.

The researchers selected a sample group that represent the population of the Higher Education Institution in Taft Avenue, Manila. Further, the participants were selected using the stratified random sampling. In this sampling methodology, the researchers divided the entire population into different subgroups, and then randomly selected the final subjects proportionally from the different programs. This technique is useful because the researchers wanted to ensure that all programs from different schools would be represented and they would like to highlight specific subgroups' various determinants in accepting or resisting the use of LMS.

This study was conducted on the 2nd Term of School Year 2017-2018 in the Higher Education Institution in Taft Avenue, Manila.

The data that were collected from the faculty comprised their complete name, ID number, gender, birthdate, and experience. Additionally, the Performance Expectancy (PE), Effort Expectancy (EE), and Social Influence (SI), and the Behavioral Intention were collected using the questionnaire derived from the Empirical Validation of Unified Theory of Acceptance and Use of Technology Model [2]. However, this study did not include respondents such as administrators, academic service faculty, staff, and students. In addition, this study did not delineate the rank and status of faculty in determining the reasons for acceptance or resistance of a learning management system. Finally, this study did not distinguish access made by faculty to different devices, such as, but not limited to, smart phones, tablets, laptops, and desktop computers.

\section{Ethical Standard}

The research indicated the ethical clause in its survey questionnaire. The researchers informed the subjects about the purpose of the study, the confidentiality of data, anonymity of subjects, and non-disclosure. The subject participation was voluntary. The study recognized the protection of the subjects from harm in the conduct of the study.

\section{Population and Sampling Technique}

The population that is considered in the study comprised of the faculty members in the College. 
Target sample size of 134 was calculated based on a medium effect size (.030) and significance level of .05. Random sampling was used to select the respondents those who are using LMS.

\section{E. Research Instrument}

The study used a standardized survey questionnaire from UTAUT. This was self-administered. The instrument used the actual LMS usage as the dependent variable. The data were collected from an online survey form. The reliability of the instrument was tested by means of Cronbach alpha. Validity of the instrument was tested using Principal Component Analysis.

The instrument is composed of the sections about Personal Information and the UTAUT variables Performance Expectancy (PE), Effort Expectancy (EE), Social Information (SI), Facilitating Condition (FC) and Behavioral Intent (BI). The respondents' name (optional), birthdate, gender, LMS experience, other LMS's experience, name of LMS brand used made up the first part of the instrument. The other sections of the instrument followed the UTAUT model made up of five variables. Actual LMS usage was derived from faculty level of tools utilized (Table 2).

A 7-point Likert Scale to measure the variables PE, EE, SI, FC, and BI was adopted. The response and its equivalent point is shown in Table 1.

Table 1. Seven-Point LiKert Scale for Items in PE, EE, SI, FC AND BI

\begin{tabular}{lc}
\hline \multicolumn{1}{c}{ Response } & Point \\
Disagree & 1 \\
\hline Moderately Disagree & 2 \\
Somewhat Disagree & 3 \\
Neutral & 4 \\
Somewhat Agree & 5 \\
Moderately Agree & 6 \\
Completely Agree & 7 \\
\hline
\end{tabular}

For LMS Usage, the respondents are rated from Level 1 to 4 depending on the tools or quadrants they used. The features and tools of LMS are classified into four quadrants which are Content, Assessment, Records, and Engagement (Table 2). Level of usage depends upon the number of tools/quadrants used.

TABLE 2. Quadrants for LMS Features

\begin{tabular}{|l|l|}
\hline \multicolumn{1}{|c|}{ CONTENT } & \multicolumn{1}{c|}{ ASSESSMENT } \\
\hline Module & Dropbox \\
File Upload & Quizzes \\
Link & Rubrics \\
\hline
\end{tabular}

\begin{tabular}{|l|l|} 
Dropbox & Self-assessment \\
Import/export & Survey \\
Association & Discussion \\
\hline \multicolumn{1}{|c|}{ RECORDS } & Association \\
\hline Grade & ENGAGEMENT \\
Attendance & News \\
Seat plan & Discussion \\
Groupings & Calendar \\
Calendar & Chat \\
Association & Email \\
& Blog \\
& Intelligent agent \\
\hline
\end{tabular}

Users who are considered to be in Level 1 utilized at least one quadrant and 0 to 1 tools. Level 2 users were using from 2 to 5 tools for at least two quadrants. Faculty members who were using from 6 to 10 tools for at least three quadrants are classified as Level 3. Lastly, Level 4 users were using all quadrants and more than 10 tools [5].

\section{F. Reliability of Scale}

To assess the reliability or internal consistency of the scale used in this study, Cronbach's Alpha was used for the following constructs. The scale is made of interval data type using 7-point Likert Scale. As shown in Table 3, all constructs passed the minimum alpha coefficient requirement of 0.65 for a scale to be acceptable. The smallest alpha coefficient is 0.754 (FC) and largest is $0.986(\mathrm{BI})$. The overall reliability of the instrument is 0.948 (19 items) which is highly acceptable.

Table 3. RELIABILITY INDEX OF ITEM BASED ON CRONBACH ALPHA

\begin{tabular}{|c|c|c|}
\hline Construct & $\begin{array}{l}\mathrm{N} \text { of } \\
\text { items }\end{array}$ & $\begin{array}{c}\text { Cronbach } \\
\text { Alpha }\end{array}$ \\
\hline $\begin{array}{l}\text { Performance } \\
\text { Expectancy (PE) } \\
\text { Effort Expectancy } \\
\text { (EE) }\end{array}$ & 4 & $\begin{array}{l}0.897 \\
0.896\end{array}$ \\
\hline $\begin{array}{l}\text { Social Influence (SI) } \\
\text { Facilitating Condition } \\
\text { (FC) } \\
\text { Behavioral Intention } \\
\text { (BI) }\end{array}$ & $\begin{array}{l}4 \\
3\end{array}$ & $\begin{array}{l}0.780 \\
0.754 \\
0.986\end{array}$ \\
\hline
\end{tabular}

\section{G. Validity of Instrument}

Principal component analysis (PCA) was used to test if there are other underlying components among the factors used in the study. Table 4 indicated that all variables in $\mathrm{PE}, \mathrm{EE}, \mathrm{SI}, \mathrm{FC}$, and $\mathrm{BI}$ were reduced into 
one principal component with different variance percentage. These principal components explains $78.47 \%$ of the total variance for performance expectancy; $76.20 \%$ effort expectancy; $60.88 \%$, social influence, $57.90 \%$, facilitating condition, and $97.36 \%$ for behavioral intention. Given that the factors are similar to the principal components this validated that the scale is measuring the same constructs.

Table 4. PRINCIPAL COMPONENT ANALYSIS

\begin{tabular}{lccc}
\hline Construct & $\begin{array}{c}\text { Total } \\
\text { Variance } \\
\text { Explained } \\
(\%)\end{array}$ & Item & $\begin{array}{c}\text { Component } \\
1\end{array}$ \\
\hline Performance & 78.47 & PE1 & .93 \\
Expectancy & & PE2 & .94 \\
& & PE3 & .91 \\
Effort & 76.20 & EE1 & .87 \\
Expectancy & & EE2 & .88 \\
& & EE3 & .87 \\
Social & 60.88 & SI1 & .87 \\
Influence & & SI2 & .83 \\
& & SI3 & .73 \\
& & SI4 & .66 \\
\hline Facilitating & 57.90 & FC1 & .82 \\
Condition & & FC2 & .83 \\
& & FC3 & .69 \\
& & FC4 & .68 \\
\hline Behavioral & 97.36 & BI1 & .98 \\
Intention & & BI2 & .99 \\
\hline & & BI3 & .99 \\
\hline & & &
\end{tabular}

\section{H. Data Collection Procedure}

To collect the desired data from the faculty, a request was sent through the deans of different programs from SDA, SDEAS, SHRIM, SMIT, and SMIT detailing the purpose of the research, the required data, and the expected delivery of the requested data. To administer the survey questionnaire, a request was sent to the concerned faculty through the chairperson of the abovementioned programs. The request contains the sections that were included in the survey and the date of the supervision of the survey. The following table details the activities, purposes, output, and use of the outputs.
Table 5. Data Collection Procedure

\begin{tabular}{|l|l|l|l|}
\hline $\begin{array}{l}\text { Steps in Data } \\
\text { Collection }\end{array}$ & \multicolumn{1}{|c|}{ Purpose } & $\begin{array}{c}\text { Specific } \\
\text { Output or } \\
\text { Outcome }\end{array}$ & $\begin{array}{l}\text { Use of Output } \\
\text { or Outcome }\end{array}$ \\
\hline $\begin{array}{l}\text { 1. Pilot test } \\
\text { the research } \\
\text { instrument }\end{array}$ & $\begin{array}{l}\text { To validate } \\
\text { the accuracy } \\
\text { and } \\
\text { appropriatenes } \\
\text { s of the } \\
\text { instrument }\end{array}$ & $\begin{array}{l}\text { Test data } \\
\text { from the } \\
\text { instrument }\end{array}$ & $\begin{array}{l}\text { To get an idea } \\
\text { how the } \\
\text { subjects will } \\
\text { answer the } \\
\text { instrument. }\end{array}$ \\
\hline $\begin{array}{l}\text { 2. Analyze } \\
\text { the instrument } \\
\text { and the test } \\
\text { data }\end{array}$ & $\begin{array}{l}\text { To determine } \\
\text { sources of } \\
\text { errors/adjustm } \\
\text { ents }\end{array}$ & $\begin{array}{l}\text { Identified } \\
\text { areas of } \\
\text { errors and } \\
\text { adjustments }\end{array}$ & $\begin{array}{l}\text { To foretell what } \\
\text { will happen } \\
\text { during the data } \\
\text { collection. }\end{array}$ \\
\hline $\begin{array}{l}\text { 3. Revise the } \\
\text { instrument }\end{array}$ & $\begin{array}{l}\text { To adjust and } \\
\text { calibrate the } \\
\text { instrument }\end{array}$ & $\begin{array}{l}\text { Validated } \\
\text { instrument }\end{array}$ & $\begin{array}{l}\text { The validated } \\
\text { instrument will } \\
\text { avoid waste of } \\
\text { resources and } \\
\text { garbage data }\end{array}$ \\
\hline $\begin{array}{l}\text { 4. Secure } \\
\text { permit/authori } \\
\text { zation }\end{array}$ & $\begin{array}{l}\text { To comply } \\
\text { with ethical } \\
\text { standards }\end{array}$ & $\begin{array}{l}\text { Approved } \\
\text { Letter of } \\
\text { Authorizati } \\
\text { on }\end{array}$ & $\begin{array}{l}\text { To legal/ethical } \\
\text { purposes }\end{array}$ \\
\hline $\begin{array}{l}\text { 5. Conduct } \\
\text { the data } \\
\text { collection }\end{array}$ & $\begin{array}{l}\text { To get the } \\
\text { data for the } \\
\text { research }\end{array}$ & Actual Data & $\begin{array}{l}\text { For data } \\
\text { processing and } \\
\text { analysis }\end{array}$ \\
\hline
\end{tabular}

\section{Data Collection Procedure}

The researcher adopted the questionnaire survey from the Empirical Validation of Unified Theory of Acceptance and Use of Technology Model [6]. The LMS usage data were taken in a survey conducted in December 2017 among the faculty members. The reliability of the instrument is measured using the Cronbach Alpha analysis. Principal Component Analysis was used to reduce the variables into one or more index variable (or component). A significance level of .05 was set. Standardization of answers (Zscore) was done to normalize the data set using statistical software packages.

Descriptive statistics such as mean, standard deviation, skewness, and kurtosis were considered in describing the characteristics of the observations. Pearson Product Moment was used to compute the degree of association the dependent and independent variables.

Multiple linear regression using step-wise method was used to determine which among the independent variables significantly contributes to the explanation of the dependent variable and the strength of the relationship. Moderation analysis was conducted to determine the effect of the interaction of the moderating variable in the relationship between the dependent and dependent variable.

The researchers utilized SPSS version 21 and Microsoft Excel 2016. The succeeding table enumerates the steps, purposes, and specific outputs of the data analysis: 
Table 6. StePs, PuRPose AND OUTPUTS OF ANALYSIS

\begin{tabular}{|c|c|c|}
\hline $\begin{array}{c}\text { Steps in Data } \\
\text { Analysis }\end{array}$ & Purpose & $\begin{array}{c}\text { Specific Output } \\
\text { or Outcome }\end{array}$ \\
\hline $\begin{array}{l}\text { 1. Encoding of } \\
\text { data }\end{array}$ & Data Entry & $\begin{array}{l}\text { Data in digital } \\
\text { file }\end{array}$ \\
\hline $\begin{array}{l}\text { 2. Data } \\
\text { Validation }\end{array}$ & $\begin{array}{l}\text { To check for } \\
\text { number of } \\
\text { responses, } \\
\text { missing, } \\
\text { misencoding, } \\
\text { skewness, } \\
\text { frequencies }\end{array}$ & $\begin{array}{l}\text { Frequency } \\
\text { Distribution } \\
\text { Normal } \\
\text { Distribution }\end{array}$ \\
\hline $\begin{array}{l}\text { 3. Process the } \\
\text { data }\end{array}$ & $\begin{array}{l}\text { To generate the } \\
\text { required statistics }\end{array}$ & Statistics Graphs \\
\hline $\begin{array}{l}\text { 4. } 3.1 \text { Run } \\
\text { descriptive } \\
\text { statistics }\end{array}$ & $\begin{array}{l}\text { To describe the } \\
\text { population using } \\
\text { the sample }\end{array}$ & $\begin{array}{l}\text { Measures of } \\
\text { Central } \\
\text { Tendency }\end{array}$ \\
\hline $\begin{array}{l}\text { 5. } 3.2 \text { Run } \\
\text { correlation } \\
\text { statistics }\end{array}$ & $\begin{array}{l}\text { To determine the } \\
\text { strength of } \\
\text { relationship } \\
\text { among variables }\end{array}$ & $\begin{array}{l}\text { Pearson Product } \\
\text { Moment } \\
\text { Coefficients, } \\
\text { Correlation } \\
\text { coefficients, } \\
\text { linear regression } \\
\text { models } \\
\end{array}$ \\
\hline $\begin{array}{l}\text { 6. } 3.3 \text { Run test } \\
\text { of significance }\end{array}$ & $\begin{array}{l}\text { To test the } \\
\text { significance of the } \\
\text { correlations }\end{array}$ & $\begin{array}{l}\text { Linear regression } \\
\text { Multiple linear } \\
\text { regression } \\
\text { ANOVA, t-test } \\
\text { significance }\end{array}$ \\
\hline
\end{tabular}

\section{RESULTS AND OBSERVATIONS}

\section{A. Demographic Profile}

The distribution of faculty-respondents in terms of gender and age is shown in Table 5. The subjects of the study in terms of gender are almost balanced. Female subjects accounts to $51.5(\mathrm{~N}=52)$ percent while males is 48.5 percent $(\mathrm{N}=49)$. The age bracket with the highest frequency is between 40-59 (52\%) followed closely by $25-39(44 \%, \mathrm{~N}=40)$. Lowest registered age bracket is 61 and above (2\%), 25-below (3\%) and 41-50 (6.9\%). Data indicated that the $48 \%$ $(\mathrm{N}=48)$ of faculty used LMS between $4-6$ terms; $28 \%$ $(\mathrm{N}=29)$ between 1-3 terms. Three percent $(\mathrm{N}=3)$ had no experience in the use of the software.

Table 7. Frequency Distribution and Percentage of DEMOGRAPHIC VARIABLES

\begin{tabular}{llcc}
\hline & Bracket & Frequency & Percent \\
\hline Age & less & 2 & 2.17 \\
& than 25 & & 43.48 \\
& $25-39$ & 40 & 52.17 \\
& $40-59$ & 48 & 2.17 \\
& 60 and & 2 & 100 \\
& above & & \\
& $\mathrm{N}$ & 92 & 51.5
\end{tabular}

\begin{tabular}{llcc} 
& $\begin{array}{l}\text { Male } \\
\text { LMS }\end{array}$ & 49 & 48.5 \\
Experience & 0 & 101 & 100 \\
\hline (term) & $1-3$ & 29 & 2.97 \\
& $4-6$ & 48 & 47.52 \\
& $7-9$ & 19 & 18.81 \\
& 10 and & 2 & 1.98 \\
& above & 101 & 100 \\
\hline & $\mathrm{N}$ & &
\end{tabular}

\section{B. Experience Using LMS}

Two out of 10 teachers indicated that they used LMS for 6 terms. Majority of the teachers $(\mathrm{N}=77)$ had used the learning management system between 2 to 6 terms $(76 \%)$. The use of LMS between 7 to 12 terms is 20 percent $(\mathrm{N}=21)$.

Table 8. Faculty EXPERIENCE IN USING LMS

\begin{tabular}{ccc}
\hline Terms & Frequency & Percent \\
\hline 0 & 3 & 3.0 \\
2 & 10 & 9.9 \\
3 & 19 & 18.8 \\
4 & 14 & 13.9 \\
5 & 13 & 12.9 \\
6 & 21 & 20.8 \\
7 & 4 & 4.0 \\
8 & 6 & 5.9 \\
9 & 9 & 8.9 \\
12 & 2 & 2.0 \\
\hline Total & 101 & 100 \\
\hline
\end{tabular}

\section{LMS Level of Actual Usage}

The level of usage depends on the tools/quadrants used by the faculty. One third of teachers $(35.2 \%)$ are Level 1 users. Similar percentage are considered as level 3 users $(30.7 \%)$. Levels 2 and 3 have equal percentages $(17 \%)$.

Table 9. Descriptive Statistics of Faculty Members OF LMS USAGE

\begin{tabular}{ccc}
\hline Level & Frequency & Percent \\
\hline 1 & 31.0 & 35.2 \\
2 & 15.0 & 17.0 \\
3 & 27.0 & 30.7 \\
4 & 15.0 & 17.0 \\
\hline Total & 88.0 & 100.0 \\
Level 1: 0-1 tool and at least 1 quadrant used; Level 2: 2-3 tools and at least \\
2 quadrants used \\
Level 3 : 4-10 tools and at least 3 quadrants used; Level 4: 11 and above \\
tools and all quadrants used
\end{tabular}




\section{Descriptive Statistics for Key Variables}

The following table shows the descriptive statistics of the independent and dependent variables used in the study. Behavioral Intention to Use the System registered the highest mean $(M=6.33, S D=1.247)$ while the lowest is Social Influence $(M=5.356$, $S D=1.069$ ). The scoring utilized a 7-point Likert scale from Disagree to Completely Agree. LMS Usage used a 4-point scoring system based on the level of actual usage of the faculty. Table 10 details the descriptive statistics for the key variables.

The variables are measured in a 7-point Likert Scale. To test the assumption of normality of the data, Kolmogorov-Smirnov and Shapiro-Wilk statistics were used. Based on this test, results indicated that they do not come from a normally distributed population and significance value is below .05 .

Table 10. Descriptive Statistics For Key Variables

\begin{tabular}{ccccccc}
\hline Variable & $\mathrm{N}$ & Mean & $\begin{array}{c}\text { Std. } \\
\text { Deviation }\end{array}$ & Skewness & Kurtosis & Range \\
\hline PE & 101.00 & 5.56 & 1.26 & -1.07 & 1.10 & 6.00 \\
EE & 101.00 & 5.40 & 1.21 & -0.70 & -0.20 & 4.75 \\
SI & 101.00 & 5.36 & 1.07 & -0.71 & 0.51 & 5.00 \\
& & & & & & \\
FC & 101.00 & 5.61 & 1.02 & -0.57 & -0.58 & 3.75 \\
BI & 101.00 & 6.33 & 1.25 & -2.23 & 5.01 & 6.00 \\
LMS & 88.00 & 2.30 & 1.13 & 0.13 & -1.42 & 3.00 \\
Usage & & & & & & \\
\hline
\end{tabular}

\section{E. Intercorrelation of Variables}

Intercorrelations were made to assess the relationship among the variables i.e. Performance Expectancy, Effort Expectancy, and Social Influence. The result showed that there is a significant positive strongly correlation between Behavioral Intention with Performance Expectancy $(\mathrm{r}=.747, \mathrm{p}=.0000)$. This is followed by strong significant relationship between Effort Expectancy and Performance Expectancy $(\mathrm{r}=.673, \mathrm{p}=.000)$. Observation on the relationship between Social Influence and Performance Expectancy likewise showed a strong correlation $(\mathrm{r}=.612, \mathrm{p}=.0000)$. Although Effort Expectancy and Behavioral Intention registered the lowest among the intercorrelations, it is found to be moderately correlated. Generally, the correlations of all the variables are positive and mostly strongly related.

TABLE 11. Summary of Intercorrelations of PE, EE, SI and $\mathrm{BI}$

$\overline{\overline{\mathrm{PE}}} \overline{\mathrm{EE}} \overline{\mathrm{SI}} \overline{\mathrm{BI}}$

Performance

Expectancy (PE)

\begin{tabular}{lccc}
$\begin{array}{l}\text { Effort Expectancy } \\
\text { (EE) }\end{array}$ & $.673 * *$ & & \\
$\begin{array}{l}\text { Social Influence } \\
\text { (SI) }\end{array}$ & $.612 * *$ & $.595^{* *}$ & \\
$\begin{array}{l}\text { Behavioral } \\
\text { Intention (BI) }\end{array}$ & $.747 * *$ & $.488^{* *}$ & $.577 * *$ \\
\hline$* *$ Correlation significant at .01 level (2-tailed)
\end{tabular}

\section{F. Multiple Regression Models}

A multiple regression analysis was conducted to assess the simultaneous effects of Performance Expectancy, Effort Expectancy, and Social Influence to Behavioral Intention of faculty members to use LMS. To test assumption of linearity and distribution histogram, scatterplots were used.

Using all the variables, the general equation that predicts Behavioral Intention to use LMS from the three independent (PE, EE, and SI) variables was found to be:

$$
\mathrm{BI}=1.77+.674(\mathrm{PE})-.103(\mathrm{EE})+.256(\mathrm{SI})
$$

All independent variables were found to be significant $(\mathrm{p}<.05)$ in explaining the variation of BI except for Effort Expectancy ( $\mathrm{p}=.283$ ). The value of $\mathrm{R}^{2}$ of .586 was found to be significant (adjusted $\mathrm{R}^{2}$ $=.573$ ). (Table 12). Analysis of Variance showed that the regression is highly significant $[\mathrm{F}(3,97)=45.775$, MSResidual $=.664, \mathrm{p}<.0001)($ refer to Table 13).

The results showed (Table 12) that for every unit increase in Performance Expectancy, there is a .674 increase in Behavioral intention (BI); each unit of Effort Expectancy it decreases BI by .103; a unit increase in the BI relates to a .256 unit increase in Social Influence.

Table 12. Unstandardized Beta, Standardized Beta, AND SIGNIFICANCE OF PE, EE, AND SI COEFFICIENTS

\begin{tabular}{|c|c|c|c|c|c|}
\hline \multirow[t]{2}{*}{ Model } & \multicolumn{2}{|c|}{$\begin{array}{c}\text { Unstandardized } \\
\text { Coefficients }\end{array}$} & \multirow{2}{*}{$\begin{array}{c}\text { Standardized } \\
\text { Coefficients } \\
\text { Beta }\end{array}$} & \multirow[t]{2}{*}{$t$} & \multirow[t]{2}{*}{ Sig. } \\
\hline & B & $\begin{array}{l}\text { Std. } \\
\text { Error }\end{array}$ & & & \\
\hline (Constant) & 1.770 & .449 & & 3.944 & .000 \\
\hline PE & .674 & .094 & .680 & 7.197 & .000 \\
\hline $\mathrm{EE}$ & -.103 & .096 & -.100 & -1.080 & .283 \\
\hline SI & .256 & .102 & .220 & 2.525 & .013 \\
\hline
\end{tabular}

a. Dependent Variable: BI 
Table 13. Analysis of the VARIANCE of THE Linear REGRESSION ANOVA

\begin{tabular}{|l|r|r|r|c|l|}
\hline Model & $\begin{array}{r}\text { Sum of } \\
\text { Squares }\end{array}$ & df & $\begin{array}{c}\text { Mean } \\
\text { Square }\end{array}$ & F & Sig. \\
\hline Regression & 91.162 & 3 & 30.387 & 45.775 & $.000^{\mathrm{b}}$ \\
Residual & 64.393 & 97 & .664 & & \\
Total & 155.556 & 100 & & & \\
\hline
\end{tabular}

a. Dependent Variable: BI

b. Predictors: (Constant), SI, EE, PE

Table 14. Coefficient of Multiple RegRession Model SUMMARY

\begin{tabular}{|c|c|c|c|c|c|c|c|c|c|}
\hline \multirow[t]{2}{*}{ Model } & \multirow[t]{2}{*}{$\mathrm{R}$} & \multirow{2}{*}{$\begin{array}{c}\mathrm{R} \\
\text { Square }\end{array}$} & \multirow{2}{*}{$\begin{array}{l}\text { Adjusted } \\
\text { R Square }\end{array}$} & \multirow{2}{*}{$\begin{array}{c}\text { Std. } \\
\text { Error of } \\
\text { the } \\
\text { Estimate }\end{array}$} & \multicolumn{5}{|c|}{ Change Statistics } \\
\hline & & & & & $\begin{array}{l}\text { R Square } \\
\text { Change }\end{array}$ & $\begin{array}{c}\mathrm{F} \\
\text { Change }\end{array}$ & df1 & $\mathrm{df} 2$ & $\begin{array}{c}\text { Sig. F } \\
\text { Change }\end{array}$ \\
\hline 1 & $.766^{\mathrm{a}}$ & .586 & .573 & .814 & .586 & 45.77 & 3 & 97 & .000 \\
\hline
\end{tabular}

a. Predictors: (Constant), SI, EE, PE

\section{G. Linear Regression}

The next table shows how close the data are fitted to the regression line using the value of $\mathrm{R}$ square. There are two linear models derived from the stepwise process. On the first model (Model 1), the predictor is Performance Expectancy (PE). The second model (Model 2) includes Performance Expectancy (PE) and Social Influence (SI). Comparing the two models, the second model have the highest R square (.581) which suggest that there are two predictors to Behavioral Intention.

Table 15. STEPWISE LINEAR REGRESSION

\begin{tabular}{|c|c|c|c|c|c|c|c|c|c|}
\hline \multirow[t]{2}{*}{ Model } & \multirow[t]{2}{*}{$\mathrm{R}$} & \multirow{2}{*}{$\begin{array}{c}\mathrm{R} \\
\text { Square }\end{array}$} & \multirow{2}{*}{$\begin{array}{l}\text { Adjusted } \\
\text { R Square }\end{array}$} & \multirow{2}{*}{$\begin{array}{c}\text { Std. Error } \\
\text { of the } \\
\text { Estimate }\end{array}$} & \multicolumn{5}{|c|}{ Change Statistics } \\
\hline & & & & & $\begin{array}{l}\text { R Square } \\
\text { Change }\end{array}$ & $\begin{array}{c}\mathrm{F} \\
\text { Change } \\
\end{array}$ & df1 & df 2 & $\begin{array}{c}\text { Sig. F } \\
\text { Change }\end{array}$ \\
\hline 1 & $.747^{\mathrm{a}}$ & .558 & .554 & .832 & .558 & 125.207 & 1 & 99 & .000 \\
\hline 2 & $.762^{b}$ & .581 & .573 & .815 & .023 & 5.292 & 1 & 98 & .024 \\
\hline
\end{tabular}

a. Predictors: (Constant), PE

b. Predictors: (Constant), PE, SI

To determine if each derived model is significant, an analysis of variance was performed. Table 16 indicated that all two linear regression models are significant $(\mathrm{p}<.05)$. Model 1 showed a high significance $[\mathrm{F}(1,99)=125.207$, MSresidual=.694, $\mathrm{p}<.0001$ ) (refer to Table 16). Model 2 also displayed high significance $[F(2,98)=67.96$, MSResidual=.665, $\mathrm{p}<.0001)$.
Table 16. Analysis of VARiance of Linear Regression MODELS

ANOVA

\begin{tabular}{|ll|r|r|r|c|c|}
\hline Model & & Sum of Squares & df & Mean Square & F & Sig. \\
\hline \multirow{4}{*}{1} & Regression & 86.869 & 1 & 86.869 & 125.207 & $.000^{\circ}$ \\
& Residual & 68.687 & 99 & .694 & & \\
& Total & 155.556 & 100 & & & \\
& Regression & 90.388 & 2 & 45.194 & 67.964 & $.0000^{\circ}$ \\
2 & Residual & 65.167 & 98 & .665 & & \\
& Total & 155.556 & 100 & & & \\
\hline
\end{tabular}

a. Dependent Variable: BI

b. Predictors: (Constant), PE

c. Predictors: (Constant), PE, SI

\section{G. New Linear Regression based on Model 2}

Based on the statistics generated using Stepwise Regression, Model 2 to serves as the linear regression model for the study. Behavioral Intention can be explained by $58 \%(\mathrm{R}=.762)$ (refer to Table 15$)$ of the variations of the variables Performance Expectancy (PE), and Social Influence (SI). The linear regression is expressed as:

$$
B I=1.67+.624(P E)+.222(S I)
$$

For every unit of Performance Expectancy, there is a corresponding increase in the Behavioral Intention by .624. A unit increase in Behavioral Intention translate into a .222 unit of Social Influence.

Table 17. Two Linear Regression Models Derived FROM STEPWISE REGRESSION COEFFICIENTS

\begin{tabular}{|ll|r|r|r|r|r|}
\hline \multirow{2}{*}{ Model } & & \multicolumn{2}{|c|}{$\begin{array}{c}\text { Unstandardized } \\
\text { Coefficients }\end{array}$} & $\begin{array}{c}\text { Standardized } \\
\text { Coefficients }\end{array}$ & \multirow{2}{*}{$\mathrm{t}$} & \multirow{2}{*}{ Sig. } \\
\cline { 3 - 5 } & \multicolumn{1}{|c|}{$\mathrm{B}$} & Std. Error & \multicolumn{1}{c|}{ Beta } & & \\
\hline \multirow{2}{*}{1} & (Constant) & 2.217 & .377 & & 5.878 & .000 \\
& PE & .740 & .066 & .747 & 11.190 & .000 \\
& (Constant) & 1.669 & .439 & & 3.799 & .000 \\
2 & PE & .624 & .082 & .631 & 7.627 & .000 \\
& SI & .222 & .097 & .190 & 2.301 & .024 \\
\hline
\end{tabular}

a. Dependent Variable: BI

\section{Results OF HyPOTHESIS Testing}

The succeeding section discusses the result of the study based on the enumerated statement of the problem.

\section{A. Research Question 1}

How significant are the following variables in influencing faculty's use of LMS:

a. Performance Expectancy (PE) 
b. $\quad$ Effort Expectancy (EE)

c. $\quad$ Social Influence (SI)

d. Facilitating Condition (FC).

As seen in Table 19, the Pearson r value, Coefficient of Determination ( $\mathrm{r}$ square) and Significance were used as basis for accepting or rejecting the hypothesis.

$\mathrm{H}_{0} 1.1$ Performance Expectancy explained $56 \%$ of the variation in Behavioral Intention ( $r=.747$, $p=.000$ ). Reject the null hypothesis.

$\mathrm{H}_{0} 1.2$ Effort Expectancy explained $24 \%$ of the variation in Behavioral Intention $(r=.488$, $p=.000$ ). Reject the null hypothesis.

$\mathrm{H}_{0} 1.3$ Social Influence explained $33 \%$ of the variation in Behavioral Intention $(r=.577$, $p=.000$ ). Reject the null hypothesis

$\mathrm{H}_{0}$ 3. Behavioral Intention explained only $4 \%$ of the variation of LMS Usage $(r=.191, p=.000)$. Accept the null hypothesis.

Table 18. DifFERENT Bivariate CORRELATION CORRELATIONS INCLUDING SIGNIFICANCE AND DECISION ABOUT THE HYPOTHESES

\begin{tabular}{ccccc}
\hline Lanes & Coefficient & Significance & Hypothesis & Decision \\
\hline $\mathrm{PE} \rightarrow \mathrm{BI}$ & 0.747 & 0.00 & $\mathrm{H}_{1} . \mathrm{a}$ & Reject \\
$\mathrm{EE} \rightarrow \mathrm{BI}$ & 0.488 & 0.00 & $\mathrm{H}_{1} . \mathrm{b}$ & Reject \\
$\mathrm{SI} \rightarrow \mathrm{BI}$ & 0.577 & 0.00 & $\mathrm{H}_{1} . \mathrm{c}$ & Reject \\
$\mathrm{FC} \rightarrow \mathrm{LMS}$ & 0.147 & 0.17 & $\mathrm{H}_{1} . \mathrm{d}$ & Accept \\
$\mathrm{BI} \rightarrow$ LMS & 0.191 & 0.07 & $\mathrm{H}_{2} .0$ & Accept \\
\hline
\end{tabular}

\section{B. Research Question 2}

Do perceived Facilitating Condition have substantially affect the use of LMS among faculty?

H02. The variable Facilitating Condition did not explain the variation in the use of LMS Usage. The correlation is slightly positively correlated $(\mathrm{r}=.147)$; however the significant is greater than $.05(\mathrm{P}=.17)$. Therefore, the null hypothesis was accepted.

To test the hypothesis that the LMS Usage is a function of Facilitating Condition are moderated by factors such as Age and Experience, a hierarchical multiple regression analysis was conducted. The result showed that Age do not moderate in the relationship between Facilitating Condition and LMS Usage $(\mathrm{R} 2=.048, \Delta \mathrm{R}=.125, \mathrm{p}=.725)$. The addition of the interaction term Facilitating Condition and LMS is not significant in the linear regression model $[\mathrm{F}(3,78)=1.30, \mathrm{p}=.280]$.

Next Experience was tested for its moderating effect on the Facilitating Condition and LMS Usage. Examination of the result showed that Experience moderates between the relationship of Facilitating
Condition and LMS Usage $(\mathrm{R}=.072, \Delta \mathrm{R}=.050$, $\mathrm{p}=.037)$.

\section{Research Question 3}

Will the following moderating variables influence the strength of relationship between the independent variables and dependent variables?
a.
b.
Gender
Age
c.
Experience

Ho4. To test the effect of the moderator in the relationship between the two-variables (example: $\mathrm{PE} \rightarrow \mathrm{BI}$ ), the two variables are entered first in the regression analysis. In the second step, the two variables plus the interaction term (or the product of the independent and moderator) are included. As shown in Table 19, Age moderates in the relationship between EE and BI (R change .520, p=.012). All other relationship have no significant bearing on age. The moderator Gender did not show any effect on the relationship of the various variables ( $p>.05)$. Experience had shown to moderate between PE and BI $(\mathrm{p}=.015)$. Experience registered another moderation effect on SI and BI $(p=.014)$. The rest of the relationship had not registered any moderation to Experience.

Table 19. Summary of Moderation ANALysis

\begin{tabular}{ccccccc}
\hline Moderator & Variable & $\mathrm{N}$ & $\mathrm{df}$ & $\mathrm{t}$ & $\mathrm{R}$ change & $\mathrm{Sig}$ \\
\hline Age & PE $\rightarrow$ BI & 101 & 1,88 & -2.160 & 0.220 & 0.3300 \\
& $\mathrm{EE} \rightarrow \mathrm{BI}$ & 91 & 1,88 & -2.577 & 0.520 & $0.012^{*}$ \\
& $\mathrm{SI} \rightarrow \mathrm{BI}$ & 91 & 1,88 & -1.302 & 0.013 & 0.1960 \\
\hline \multirow{5}{*}{ Gender } & $\mathrm{PE} \rightarrow \mathrm{BI}$ & 101 & 1,97 & 0.713 & 0.002 & 0.4780 \\
& $\mathrm{EE} \rightarrow \mathrm{BI}$ & 92 & 1,88 & -0.775 & 0.005 & 0.4400 \\
& $\mathrm{SI} \rightarrow \mathrm{BI}$ & 100 & 1,97 & -1.081 & 0.000 & 0.9400 \\
\hline Experience & PE $\rightarrow$ BI & 100 & 1,97 & 2.486 & 0.026 & $0.015^{*}$ \\
& $\mathrm{EE} \rightarrow \mathrm{BI}$ & 100 & 1,97 & -0.494 & 0.002 & 0.6230 \\
& $\mathrm{SI} \rightarrow \mathrm{BI}$ & 100 & 1,97 & -2.495 & 0.036 & $0.014^{*}$ \\
\hline
\end{tabular}

* Moderator significant $(\mathrm{p}<.05)$

Based on the model used in this study, correlation coefficients were calculated to test the relationship of the various variables (see Table 17). The decision on the effect of the moderating variables (result numbers 7-9) is tabulated in Table 18.

The summary of the results of hypothesis testing are shown as follows:

1. Performance Expectancy is significantly related to Behavioral Intention.

2. Effort Expectancy is significantly associated with Behavioral Intention.

3. Social Influence is significantly related with Behavioral Intention.

4. Facilitating condition is not significantly linked with LMS Usage. 
5. Behavioral Intention is not significantly related with LMS Usage.

6. Age has a moderating effect between EE and BI.

7. Gender does not have a moderating effect between $\mathrm{PE} \rightarrow \mathrm{BI}, \mathrm{EE} \rightarrow \mathrm{BI}$, and $\mathrm{SI} \rightarrow \mathrm{BI}$.

8. Experience has a moderating effect between $\mathrm{PE} \rightarrow \mathrm{BI}$ and $\mathrm{SI} \rightarrow \mathrm{BI}$.

9. Age has no moderating effect between Facilitating Condition and LMS Usage.

10. Experience has a moderating effect between Facilitating Condition and LMS Usage.

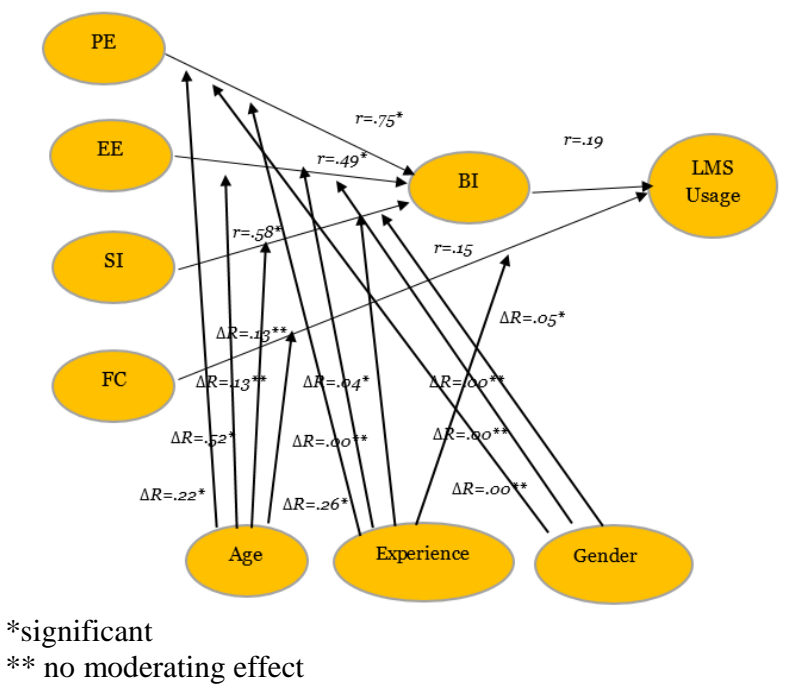

Fig. 4. Summary of Correlation Coefficient, Significance, and R Change for Independent, Dependent, and Moderating Variables

\section{CONCLUSION}

The empirical testing of UTAUT model to LMS usage confirmed that the variables PE, EE SI are determinants to BI. The correlation of BI to LMS Usage was considered as not significant. Facilitating condition; however, had not substantially shown significant relationship with LMS Usage. Moderating variables like age and experience indicated interaction effect to some of the relationship. Age had shown moderation between EE and BI. Experience had shown significant moderating effect on $\mathrm{PE}$ to $\mathrm{BI}$, SI to BI, and FC-LMS Usage.

Based on stepwise regression analysis, the derived multiple linear regression equation is:

$\mathrm{BI}=1.67+.624(\mathrm{PE})+222(\mathrm{SI})$. Effort Expectancy was removed from the three original constructs related to behavioral intent in the UTAUT model.

While the study showed that there was a strong behavioral intention of faculty members to use the system, this variable did not translate into substantial level of LMS actual usage. LMS experience also did not relate to the level of usage. This observation on the gap between the level of usage and intention can probably be attributed to the other possible factors such as: subject being taught and the availability of computers in the classroom.

Further research is needed to explore other determinants of learning management usage such as readiness and other psychometric constructs on technology acceptance.

\section{REFERENCES}

[1] O. P. Hall. (2013). Assessing Faculty Attitudes Toward Technological Change in Graduate Management Education. MERLOT Journal of Online Learning and Teaching, 39-51.

[2] E. W. Black, D. Beck, K. Dawson, S. Jinks \& M DiPietro. (2007). The other side of the LMS: Considering implementation and use in the adoption of an LMS in online and blended learning environments. TechTrends, 35-53.

[3] S. Mouakket \& A. M. Bettayeb. (2015). Investigating the factors influencing continuance usage intention of Learning management systems by university instructors: The Blackboard system case. International Journal of Web Information Systems, 491-509.

[4] J. E. Klobas \& T. J. McGill. (2010). The role of involvement in learning management system," Journal of Computing in Higher Education, 114-134

[5] J. R. B. Dela Cruz. (2017). Interviewee, BigSky Tool Usage Teacher Leveling. [Interview].

[6] V. Venkatesh, M. G. Morris, G. B. Davis \& F. D. Davis. (2003). User acceptance of information technology: Toward a unified view. MIS Quarterly, 425-478.

[7] C. Buabeng-Andoh. (2012). Factors influencing teachers' adoption and integration of information and communication technology into teaching: A review of the literature. International Journal of Education and Development using Information and Communication Technology, 8(1), 136-155.

[8] E. T. Lwoga \& M. Komba. (2014). Antecedents of continued usage intentions of web-based learning management system in Tanzania. Education + Training, 5(7), 738-756.

[9] O. Olatubosun, F. Olusoga \& A. P. Shemi. (2014). Direct Determinants of User Acceptance and Usage behavior of eLearning System in Nigerian Tertiary Institution of Learning. Journal of IT and Economic Development, 5(2), 95-111.

[10] M. Kocaleva, I. Stojanovic \& Z. Zdravev. (2015). Model of e-Learning Acceptance and Use for Teaching Staff in Higher Education Institutions. I.J. Modern Education and Computer Science, 7(4), 2331.

[11] E. Okyere-Kwakye, K. M. Nor \& A. C. Ologbo. (2016). Technology Acceptance: Examining the Intentions of Ghanaian Teachers to Use Computer for 
Teaching. African Journal of Library, Archives and Information Science, 26(2), 119-132.

[12] Z. F. Muhsen, A. Maaita, A. Odah \& A. Nsour. (2013). Moodle and e-learning tools. I.J. Modern Education and Computer Science, 1-8.

[13] X. Gu, Y. Zhu \& X. Guo. (2012). Meeting the "Digital Natives": Understanding the Acceptance of Technology in Classrooms. Educational Technology \& Society, 16(1), 392-402.

[14] E. Dogoriti, J. Pange \& G. S. Anderson. (2014). The use of social networking and learning management systems in English language teaching in higher education. Campus-Wide Information Systems, 31(4), 254-263.

[15] N. M. Radwan, M. B. Senousy \& A. E. D. M. Riad. (2014). Current trends and challenges of developing and evaluating learning management systems. International Journal of e-Education, 4(5), 361-375.

[16] N. G. Nicolau \& M. L. Popescu. (2013). E-learning Innovations in Higher Education. Romanian Review of Social Sciences, 34-47.

[17] A. R. Muhammad \& S. M. Abdulrahman. (2015). Cloud Computing Based e-Learning: Opportunities and Challenges for Tertiary Institutions in Nigeria. International Journal of e-Education, e-Business, $e$ Management and e-Learning, 5(3), 144-152.

[18] S. B. Dias \& J. A. Diniz. (2014). Towards an Enhanced Learning Management System for Blended Learning in Higher Education Incorporating Distinct Learners' Profiles. Educational Technology \& Society, 307-319.

[19] G. K. Wong. (2015). Understanding technology acceptance in pre-service teachers of primary mathematics in Hong Kong," Australasian Journal of Educational Technology, 31(6), 713-735.

[20] G. Samarawickrema \& E. Stacey. (2017). Adopting web-based learning and teaching: A case study in higher education. Distance Education, 38(3), 313333.

[21] C. Normand, A. Littlejohn \& I. Falconer. (2018). A model for effective implementation of flexible programme delivery. Innovations in Education and Teaching International, 45(1), 25-36.

[22] S. Al-Senaidi, L. Lin \& J. Poirot. (2009) . Barriers to adopting technology for teaching and learning in Oman. Computers \& Education, 53(3), 575-590.

[23] H. B. Hussein. (2011). Attitudes of Saudi Universities Faculty Members towards Using Learning Management System (JUSUR). The Turkish Online Journal of Educational Technology, 10(2), 43-53.

[24] D. S. Walker, J. R. Lindner, T. P. Murphrey \& K. Dooley. (2016). Learning Management System Usage: Perspectives From University Instructors. The Quarterly Review of Distance Education, 41-50.

[25] D. A. Falvo and B. F. Johnson. (2007) . "The use of learning management systems in the United States," TechTrends, pp. 40-45.

[26] F. D. Davis, R. P. Bagozzi \& P. R. Warshaw. (1989). User Acceptance of Computer Technology: A
Comparison of Two Theoretical Models. Management Science, 35(8), 982-1003.

[27] E. T. Straub. (2009). Understanding technology adoption: Theory and future directions for informal learning. Review of Educational Research, 79(2), 625-649.

[28] S. Y. Park. (2009). An Analysis of the Technology Acceptance Model in Understanding University Students' Behavioral Intention to Use e-Learning. Educational Technology \& Society, 12(3), 150-162.

[29] N. D. Oye, N. A.Iahad \& N. Ab.Rahim. (2014). The history of UTAUT model and its impact on ICT acceptance and usage by academicians. Education and Information Technologies, 19(1), 251-270.

[30] F. D. Davis. (1989). Perceived Usefulness, Perceived Ease of Use, and User Acceptance of Information Technology. MIS Quarterly, pp. 319-340.

[31] A. Göğüş, N. Nistor, R. W. Riley \& T. Lerche. (2012). Educational technology acceptance acrros cultures: a validation of the Unified Theory of Acceptance and Use of Technology in the context of Turkish National Culture. The Turkish Online Journal of Educational Technology, 11(4), 394-408.

[32] S. Taylor \& P. A. Todd. (1995). Understanding Information Technology Usage: A Test of Competing Models. Institute for Operations Research and the Management Sciences, 6(2), 144176.

[33] M. D. Williams, N. P. Rana \& Y. K. Dwivedi. (2015). The unified theory of acceptance and use of technology (UTAUT): a literature review. Journal of Enterprise Information Management, 28(3), 443488.

[34] A. A. AlQudah. (2014). Accepting Moodle by Academic Staff at the University of Jordan: Applying and Extending TAM in Technical Support Factors. European Scientific Journal, 10(18), 183-200.

[35] A. C. M. O. Robles. (2017). Evaluating the use of Toondoo for Collaborative E-Learning of Selected Pre-Service Teachers. I.J. Modern Education and Computer Science, 9(11), 25-32.

[36] D. E. Marcial. (2012). Teaching and Learning with Technology in Higher Education Institutions in the Philippines. PeLS Online Journal, 3(3), 50-66.

[37] R. C. Raga, Jr. \& J. D. Raga. (2017). Monitoring Class Activity and Predicting Student Performance Using Moodle Action Log Data. International Journal of Computing Sciences Research, 1(3), 1-16.

[38] M. N. Tolentino. (2011). University Web Portals As Information Management Tool: Technology Acceptance Dimension. International Journal of Management \& Information Systems, 15(3), 31-40.

[39] E. R. Red, H. G. S. Borlongan, T. T. Briagas \& M. J. M. Mendoza. (2013). An Assessment of the eLearning Readiness State of Faculty Members and Students at Malayan Colleges Laguna. International Journal of the Computer, the Internet and Management, 1, 20-26.

[40] M. A. S. Enriquez. (2014). Students' Perceptions on the Effectiveness of the Use of Edmodo as a 
Supplementary Tool for Learning. in DLSU Research Congress 2014, Manila.

[41] C. T. Sumande, C. L. Castolo \& B. E. V. Comendador. (2016). The ICT Level of Confidence of Course Specialists in Distance Education: The Polytechnic University of the Philippines Experience. Turkish Online Journal of Distance Education, 17(4), 175-189.

[42] C. D. Lim. (2016). Exploring Educational Platforms and Community Behavior to support DLSU Online Blended Learning Initiative. in DLSU Research Congress 2016, Manila.

[43] S. Kim, K. H. Lee, H. Hwang \& S. Yoo. (2016). Analysis of the factors influencing healthcare professionals' adoption of mobile electronic medical record (EMR) using the unified theory of acceptance and use of technology (UTAUT) in a tertiary hospital. BMC Medical Informatics and Decision Making, 16(1), 12.

[44] R. J. Holden \& B. T. Karsh. (2010). The Technology Acceptance Model: Its Past and Its Future In Health Care. Journal of biomedical informatics, 43(1), 159172.

[45] T. Sundaravej. (2010). Empirical validation of unified theory of acceptance and use of technology model. Journal of Global Information Technology Management, 13(1), 527. 